\title{
AKIBAT HUKUM DARI AKTA JUAL BELI TANAH DIHADAPAN PPAT YANG DIBUAT TIDAK SESUAI DENGAN PROSEDUR PEMBUATAN AKTA PPAT
}

\author{
Istanti $^{*}$, Akhmad Khisni ${ }^{* *}$ \\ * Mahasiswa Program Magister (S2) Kenotariatan Fakultas Hukum UNISSULA, Semarang email: \\ istanti776@gmail.com \\ Dosen Fakultas Hukum UNISSULA, Semarang
}

\section{ABSTRACTS}

This research aims to know and analyse which kind of drawing up the land buying-selling certificate categorized as appropriate or not appropriate with the procedures of drawing up a deed by the land certificate issuing officers, and what the legal effect of this procedural distortions is, as stated above.

Sociological-empirical research methode which is characterized as descriptive analytic research is applied in this research. Morover, the approach methode applied in this research is empirical juridical qualitative approach with a specification on a prescriptive research. The primary data sources are direct interviews, whereas the secundary data sources are data taken from the primary, secondary and tertiary data. The data collecting is executed by making use of literary studies, interviews and qualitative data analysis.

The research findings analyse the buying-selling deed processed in front of the land certificate issuing officers, but which is not executed appropriately in the right procedures. This unprocedural process of drawing up the land deed related to the land buying-selling certificate, is caused by certain situations and conditions of the buyingselling rights executed in front of the officers which are compulsory. Officers are willing to ignore the procedures of drawing a buying-selling certificate as ordered in Government Order No. 37 / 1998 regarding Orders on Officers of Land Certificate Issuing Officer, and Government Order No. 24 / 1997 regarding Land Registration and its executional procedures.

Negative effects of the actions done by the land certificate issuing officers who ignore the real procedures, are that, firstly, the deed can be degraded, and secondly, the officers can be punished to be guilty as a result of their incorrect actions.

Keywords : legal effects, deed drawn up by the land certificate issuing officer, buying-selling, procedures.

\section{PENDAHULUAN}

Indonesia merupakan negara yang terdiri atas laut dan darat yang kaya akan hasil bumi yang ada. Kebutuhan pokok manusia amatlah beragam mulai dari pakaian, makanan, minuman yang diperoleh dari pengolahan tanah. Adanya tanah beserta pengaturan dan penggunaannya adalah sangat penting dikarenakan merupakan kunci dari eksistensi manusia.

Tanah mempunyai fungsi ganda yaitu sebagai social asset dan sebagai capital assetdalam kehidupan manusia yang merupakan salah satu modal dalam rangka pembangunan nasional. Yang dimaksud social assetdisini, tanah berperan sebagai sarana pengingat kesatuan sosial bagi masyarakat Indonesia. Sedangkan yang dimaksud tanah berfungsi sebagai capital asset adalahtanah merupakan bahan perniagaan dan sebagai obyek spekulasi. Maka dari itu semakin meningkatnya kebutuhan akan tanah maka akan semakin terbatasnnya persediaan akan tanah, maka sesuai dengan hukum permintaan dan penawaran, yang akan menimbulkan sengketa pertanahan ataupun konflik-konflik pertanahan. Untuk mengantisipasi adanya sengketa pertanahan maupun konflik-konflik yang akan terjadi dibutuhkan perangkat hukum dan sistem administrasi pertanahan yang rapi dan teratur, sehingga dapat menjamin dan dapat memberikan perlindungan hukum terhadap pemilik tanah serta dapat mengatur mengenai kepemilikan, peralihan dan peruntukan tanah secara adil dan menyeluruh.

Dalam Pembukaan Undang-Undang Dasar 1945 dan Pasal 33 ayat (3) Undang-Undang Dasar 1945 yang berbunyi : 
"Bumi, air dan kekayaan alam yang terkandung didalamnya dikuasai oleh Negara dan dipergunakan sebesar-besarnya untuk kemakmuran rakyat"

tertuang cita-cita luhur dari Bangsa Indonesia untuk dapat memberi perlindungan hukum terhadap pemilik tanah, mengatur kepemilikan, peralihan dan peruntukan tanah yang adil dan menyeluruh.

Untuk itu diciptakanlah Undang-Undang Pokok Agraria (UUPA) atau Hukum Agraria Nasional yang pada tanggal 24 September 1960disahkan oleh Bapak Soekarno selaku Presiden Republik Indonesia dan diundangkan di Lembar Negara Republik Indonesia nomor 104 Undang-Undang Nomor 5 Tahun 1960 tentang Peraturan Dasar Pokok-Pokok Agraria yang dikenal sebagai Undang-Undang Pokok Agraria (UUPA).

Dengan diundangkannya Undang-Undang Pokok Agraria (UUPA) pada tanggal tersebut, maka pada tanggal 24 September 1960 tercatat sebagai salah satu tanggal dan merupakan salah satu tonggak yang sangat penting dalam sejarah perkembangan agraria/pertanahan di Indonesia pada khususnya. ${ }^{1}$ Dengan dikeluarkannyaUndang-Undang Pokok Agraria (UUPA) atau Undang-Undang Nomor 5 Tahun 1960 ini, maka berlakunya peraturan hukum dari Tanah Kolonial, dualisme dan pluralisme hukum tanah di Indonesia telah berakhir.Dalam Penjelasan Umum dinyatakan Undang-Undang Pokok Agraria menciptakan Hukum Agraria Nasional berstruktur tunggal, bahwa UUPA atas dasar Hukum Adat tentang tanah, sebagai hukum aslinya bagian terbesar rakyat Indonesia. ${ }^{2}$ UUPA adalah aturan dasar tentang pokok-pokok agraria dan landasan hukum tanah nasional, tidak memberikan pengertian yang tegas, baik mengenai istilah "tanah" maupun istilah "agraria". Dari ketentuan Pasal 1 ayat (4), (5) dan (6) jo Pasal 2 ayat (1) UUPA ditarik kesimpulan yaitu pengertian luas mengenai keagrariaan meliputi bumi, air, ruang angkasa dan kekayaan alam yang terkandung didalamnya.

Dengan adanya Undang-Undang Pokok Agraria ini, mendasarkan pasal 33 ayat (3) Undang-Undang Dasar 1945 terutama kata-kata "dikuasai oleh Negara", seperti ternyata dalam pasal 2 ayat (2) UUPA, maka Negara sebagai organ tertinggi yang berwenang menguasai seluruh tanah.

\footnotetext{
${ }^{1}$ Boedi Harsono, Hukum Agraria Indonesia, Sejarah pembentukan Undang-Undang Pokok Agraria, Isi dan pelaksanaannya, (Jakarta, Djambatan, 2007). Hal. 3

${ }^{2}$ Ibid, hal 2
}

Yang merupakan tujuan dari Undang-Undang Pokok Agraria adalah memberikan kepastian hukum bagi seluruh warga negara Indonesia mengenai hakhak atas tanah, untuk itu diperlukannya pendaftaran tanah yang mempunyai 5 (lima) asas pendaftaran Hak Milik atas Tanah yaitu asas sederhana, asas aman, asas terjangkau, asas mutakhir serta asas terbuka yang harus dipedomani oleh para pendaftar maupun PPAT yang berwenang. Hal ini sesuai dengan ketentun Pasal 19 ayat (1) UUPA.

Pemerintah Republik Indonesia telah mengeluarkan PP No. 10 Tahun 1961 tentang Pendaftaran Tanah guna melaksanakan Pasal 19 Undang-Undang Pokok Agraria. Namun kenyataannya pendaftaran tanah yang mendasarkan PP No. 10 Tahun 1961 tersebut ternyata pelaksanaan maupun hasilnya tidak sesuai dengan harapan pihak pemerintah. PP 24 Tahun 1997 menjelaskan mengenai ketidak sesuaian tersebut. Hal ini dijelaskan dalam "penjelasan umum" peraturan pemerintah nomor 24 tahun 1997 tentang pendaftaran tanah yang antara lain berbunyi sebagai berikut :

Peraturan pemerintah nomor 24 tahun 1997 tentang Pendaftaran Tanah menyebutkan yang dimaksud dengan pendaftaran tanah sebagaimana disebut oleh Pasal 1 ayat (1) adalah :

Pendaftaran tanah adalah rangkaian kegiatan yang dilakukan oleh Pemerintah secara terus menerus berkesinambungan dan teratur, meliputi pengumpulan, pengolahan, pembukuan, dan penyajian serta pemeliharaan data fisik dan data yuridis, dalam bentuk peta dan daftar, mengenai bidang-bidang tanah dan satuan-satuan rumah susun, termasuk pemberian surat tanda bukti haknya bagi bidang-bidang tanah yang sudah ada haknya dan hak milik atas satuan rumah susun serta hak-hak tertentu yang membebaninya.

Dalam PP no. 24 Tahun 1997 tentang Pendaftaran Tanah yang menggantikan PPno. 10 tahun 1961 tentang Pendaftaran Tanah, tetap dipertahankan dengan tujuan penyelenggaraan pendaftaran tanah pada hakekatnya telah ditetapkan Undang-Undang Pokok Agraria dalam Pasal 19, yaitu bahwa pendaftaran tanah merupakan tugas pemerintah yang diselenggarakan dalam rangka menjamin kepastian hukum di bidang pertanahan.

Tujuan Pendaftaran tanah adalah sebagaimana tercantum dalam Pasal 3 Peraturan Pemerintah Nomor 24 Tahun 1997 tentang Pendaftaran Tanah. Pendaftaran hak dan pendaftaran peralihan hak atas 
tanah ini sebagaimana diatur dalam pasal 19 ayat 2 sub b UUPA, merupakan sebagian dari tugas dan wewenang Pemerintah di bidang pendaftaran tanah. Di bidang ini, pendaftaran hak dan pendaftaran peralihan hak dapat dibedakan 2 tugas, yaitu :

1. Pendaftaran hak atas tanah, adalah pendaftaran hak untuk pertama kalinya atau pembukuan suatu hak atas tanah dalam daftar buku tanah.

2. Pendaftaran hak atas peralihan hak atas tanah. ${ }^{3}$

Kegiatan Pendaftaran Hak atas Tanah, dilaksanakan oleh PPAT, sesuai dengan ketentuan tentang Peraturan Jabatan PPAT yakni Nomor 37 Tahun 1998 Tentang Peraturan Jabatan Pembuat Akta Tanah, yang pada pasal 2 menyatakan :

(1) PPAT bertugas pokok melaksanakan sebagian kegiatan pendaftaran tanah dengan membuat akta sebagai bukti telah dilakukannya perbuatan hukum tertentu mengenai hak atas tanah atau Hak Milik Atas Satuan Rumah Susun, yang akan dijadikan dasar bagi pendaftaran perubahan data pendaftaran tanah yang diakibatkan oleh perbuatan hukum itu.

(2) Perbuatan hukum sebagaimana dimaksud pada ayat (1) adalah sebagai berikut:
a. Jual beli;
b. Tukar menukar;
c. Hibah;
d. Pemasukan kedalam perusahaan (inbreng);
e. Pembagian Hak Bersama;
f. Pemberian Hak Guna Bangunan/Hak Pakai atas Tanah Hak Milik;
g. Pemberian Hak Tanggungan;
h. Pemberian Kuasa Membebankan Hak Tanggungan;

Pejabat Pembuat Akta Tanah diangkat oleh pemerintah, dalam hal ini Badan Pertanahan Nasional dengan tugas dan kewenangan tertentu dalam rangka melayani kebutuhan masyarakat akan akta pemindahan hak atas tanah, akta pembebanan hak atas tanah, dan akta pemberian kuasa pembebanan hak tanggungan sebagaimana diatur dalam peraturan perundang-undangan yang berlaku. ${ }^{4}$

\footnotetext{
${ }^{3}$ Ali Achmad Chomsah, Hukum Agraria (Pertanahan Indonesia) Jilid 2, (Jakarta, Prestasi Pustaka Publiser, 2004) hal. 37

${ }^{4}$ Jimly Asshiddiqi, Independen dan Akuntabilitas Pejabat Pembuat Akta Tanah, Majalah Renvoi Edisi 3 Juni 2003, hal 31
}

Dalam perkembangan pendaftaran tanah yang berlaku di Indonesia, tugas dan kewajiban PPAT sebagai pejabat umum diatur melalui berbagai macam peraturan perundang-undangan yaitu :

1. UU No 4 Tahun 1996 tentang Hak Tanggungan atas tanah beserta benda-benda yang berkaitan dengan tanah.

Pengertian PPAT sebagaimana diatur dalam Pasal 1 ayat (4) Undang-Undang Hak Tanggungan.

2. PP No 24 Tahun 1997 tentang Pendaftaran Tanah yang diatur dalam Pasal 1 angka 24.

3. PP No 37 Tahun 1998 tentang Peraturan Jabatan Pejabat Pembuat Akta Tanah, secara khusus diatur dalam Pasal 1 butir 1 .

Pendaftaran Tanah di Indonesiapun semakin berkembangan, Badan Pertanahan Nasional pada tanggal 27 Desember 2012 telah mengeluarkan peraturan baru yakni Peraturan Kepala Badan Pertanahan Nasional Republik Indonesia Nomor 8 Tahun 2012 (Perka BPN 8/2012), melalui Badan Pertanahan Nasional (BPN) Pusat, membuat langkahlangkah yang strategis guna memberikan pelayanan terutama terhadap hubungan Kantor Pertanahan dengan PPAT. Langkah strategis itu tidak lain adalah mengeluarkan sebuah peraturan yang dimungkinkan setiap PPAT dalam menjalankan jabatannya membuat desain sendiri akta-akta yang berhubungan di bidang pertanahan, baik yang menyangkut peralihan hak seperti Jual Beli, Tukar Menukar, Hibah, Pemasukan kedalam Perusahaan, akta Pembagian Hak Bersama. ${ }^{5}$ Sedangkan dalam bidang jaminan (pertanggungjawaban) pembuatan APHT, AKMHT maupun juga pelayanan pembuatan akta Pemberian HGB atau HP atas tanah HM. Sebelumnya Badan Pertanahan Nasional setempat telah menyediakan blangko guna peralihan hak dan pembenan hak yang akan dilakukan oleh para Pejabat Pembuat Akta Tanah.

Akta yang dibuat oleh Pejabat Pembuat Akta Tanahadalah salah satu sumber utama dalam hal penertiban pendaftaran tanah yang ada di Indonesia. PPAT sudah dikenal sejak berlakunya Peraturan Pemerintah Nomor 10 Tahun 1961 tentang Pendaftaran Tanah, yang merupakan peraturan tanah sebagai pelaksana UUPA. ${ }^{6}$ Untuk menjamin kepastian hukum telah dilakukannya suatu perbuatan

\footnotetext{
${ }^{5}$ Bambang S. Oyong, 2013, "Peraturan KBPN Nomor 8 tahun 2012, "Peraturan nomor 8 tahun 2012 dalam kajian Tugas Pekerjaan PPAT, URL : http://bambangoyong.blokspot.com

${ }^{6}$ Boedi Harsono, op. cit. hal.74
} 
hukum tentang peralihan maupun pembebanan oleh para pihak, peralihan hak harus dibuat dengan akta otentik dimana akta tersebut harus dibuat dihadapan pejabat yang ditunjuk/berwenang untuk itu agar dapat dipergunakan sebagai bukti yang sempurna. Hal ini dimaksud untuk menjamin kepastian hukum mengenai hak serta kewajiban bahkan akibat hukum oleh para pihak.

Akta PPAT merupakan salah satu sumber data bagi pemeliharaan data pendaftaran tanah, maka wajib dibuat sedemikian rupa sehingga dapat dijadikan dasar yang kuat untuk pendaftaran pemindahan dan pembebanan hak yang bersangkutan. Oleh karena itu PPAT bertanggung jawab untuk memeriksa syarat-syarat untuk sahnya perbuatan hukum yang bersangkutan. Antara lain dengan mencek bersih sertifikat atau mencocokkan data yang terdapat dalam sertipikat dengan daftardaftar yang ada di Kantor Pertanahan. ${ }^{7}$

Prosedur dan aturan mengenai pembuatan akta otentik adalah ketentuan hukum yang memaksa, artinya prosedur pembuatan itu harus dilaksanakan dengan baik tanpa boleh dilanggar sedikitpun. Penyimpangan dari prosedur pembuatan akta otentik tersebut akan berakibat hukum pada kekuatan pembuktian akta sebagaimana tersebut.

Pasal 1868 KUHPerdata mengatur tentang akta otentik dan pejabat umum di Indonesia. Pasal tersebut menghendaki adanya Undang-Undang organik yang mengatur tentang bentuk akta otentik dan pejabat umum, tidak mengatur tentang blangko akta otentik.

Sementara dalam Peraturan Pemerintah Nomor 37 Tahun 1998 tentang peraturan jabatan Pejabat Pembuat Akta Tanah merumuskan "Pejabat Pembuat Akta Tanah adalah pejabat umum yang berwenang membuat akta otentik ..." kata-kata membuat dikandung arti dalam pengertian yang luas yaitu memproduksi akta sesuai dengan bentuk yang telah ditetapkan Undang-Undang mulai dari persiapan, penyusunan serta pembuatan akta sesuai dengan bentuk yang ditetapkan. Pejabat Pembuat Akta Tanahadalah pejabat umum yang berwenang membuat akta-akta tentang tanah oleh karenanya harus mampu dan cakap dalam bidang pertanahan supaya akta yang dikeluarkannya tidak mengakibatkan permasalahan dikemudian hari mengingat akta yang dibuatnya merupakan suatu

\footnotetext{
${ }^{7}$ Ibid, hal. 507
}

akta otentik yang dapat digunakan sebagai alat bukti yang sempurna.

Akta Pejabat Pembuat Akta Tanah berfungsisebagai syarat yang tegasyang digunakan untuk dasar pendaftaran perubahan dan peralihan hak serta perubahan data pendaftaran tanah, hal ini termuat dalam Pasal 96 ayat 1, ayat 2 dan ayat 3 Peraturan Menteri Negara Agraria/Kepala Badan Pertanahan Nasional Nomor 3 Tahun 1997 tentang Ketentuan Pelaksanaan Peraturan Pemerintah Nomor 24 Tahun 1997 tentang Pendaftaran Tanah sebagaimana telah diubah dengan Peraturan Kepala Badan Pertanahan Nasional Nomor 8Tahun 2012.

Prosedur dan peraturan pembuatan akta otentik adalah suatu ketentuan hukum yang bersifat memaksa, artinya prosedur pembuatan itu harus dilaksanakan setepat-tepatnya tanpa boleh dilanggar sedikitpun. Penyimpangan dari prosedur pembuatan akta otentik berakibat kepada kekuatan pembuktian akta itu.

\section{PEMBAHASAN}

\section{Tinjauan Umum Tentang Hukum Agraria}

Agraria dalam arti luas meliputi permukaan bumi, air, pertambangan dan ruang angkasa. Sedangkan agraria dalam arti sempit hanya meliputi bumi atau tanah saja. Sedangkan Hukum agraria itu sendiri ialah sejumlah aturan hukum yang mengatur tentang hak-hak penguasaan atas sumber daya alam.

Sebelum diberlakukannya Undang-Undang Pokok Agraria (UU no. 5 Tahun 1960) hukum agraria masih mempunyai sifat dualisme yaitu dengan berlakunya hukum agrariayang didasarkan hukum adat disamping hukum agraria yang didasarkan hukum barat. Jadi pada waktu itu disamping belum adanya unifikasi hukum juga belum adanya kodifikasi hukum.

Unifikasi hukum adalah ada kesatuan hukum masaah pertanahan, maksudnya tidak diatur di berbagai peraturan tetapi disatukan di UndangUndang Pokok Agraria dan peraturan pelaksanaannya.

Kodifikasi hukum adalah dibukukannya semua peraturan tentang pertanahan sehingga pihak-pihak yang berkepentingan/yang bersangkutan akan dengan mudah mengetahui ketentuan hukum yang mengatur tentang tanah yang dimilikinya dan mengetahui tentang hak, wewenang dan kewajiban yang harus dilakukannya.

Setelah dikeluarkannya Undang-Undang Pokok 
Agraria yang mencabut buku II Kitab UndangUndang Hukum Perdata sepanjang yang mengenai bumi, air serta kekayaan alam yang terkandung didalamnya, kecuali ketentuan-ketentuan mengenai hypotheek yang masih berlaku pada mulai berlakunya undang-undang ini.

Namun kembali seiring dengan berjalannya waktu makin banyak pula pelanggaran tindak pidana tentang pertanahan yang ada di negeri ini, terutama tentang permohonan hak milik yang sering kali demi kepentingan pribadi banyak pihak yang menyalah gunakan proses permohonan pembuatan sertifikat hak milik atas tanah. Hal ini dibuktikan dengan makin banyaknya sertifikat palsu yang dengan mudahnya muncul dan dikeluarkan di negeri ini. Tentunya hal ini sangat meresahkan warga, terutama menyangkut hak mereka terhadap sebidang tanah yang sangat mudah sekali dirampas oleh para pihak yang tidak bertanggung jawab. Kekuatan alat bukti yang mereka miliki berupa sertifikat hak milik seakan menjadi selembar kertas yang tidak ada harganya dan tidak ada gunanya. Sudah pasti keadaan seperti ini tidak bisa begitu saja kita anggap sebagai keadaan yang tidak berbahaya sama sekali namun sebaliknya.

Menurut Pasal 2 UUPA tahun 1960 pendaftaran atas sebidang tanah harus dilaksanakan berdasar asas sederhana, aman, terjangkau, mutakhir dan terbuka.

1. Asas sederhana : ketentuan-ketentuan pokok maupun prosedur pendaftaran Tanah dengan mudah dapat dipahami oleh pihak-pihak yang berkepentingan, terutama para pemegang hak.

2. Asas aman : diselenggarakan dengan teliti dan cermat, sehingga hasilnya dapat memberikan jaminan kepastian hukum sesuai dengan tujuannya.

3. Asas terjangkau : pihak-pihak yang memerlukannya, terutama golongan ekonomi lemah, dapat menjangkau kepastian hukum sesuai dengan tujuannya.

4. Asas mutakhir : data yang tersedia harus menunjukkan keadaan mutakhir, sehingga perlu diikuti kewajiban mendaftar dan mencatat perubahan-perubahan yang terjadi.

5. Asas terbuka : dipeliharanya data pendaftaran tanah secara terus menerus dan berkesinambungan sehingga data yang tersimpan di Kantor Pertanahan selalu "up to date"sesuai dengan kenyataan di lapangan.

Hal ini bertujuan sebagaimana tercantum dalam
Pasal 3 UUPAtahun 1960).

\section{Tinjauan Umum Tentang Peralihan Hak Atas Tanah}

\section{Pendaftaran Tanah}

Peranan tanah benar-benar mempunyai nilai yang sangat tinggi, Karena terkait erat dengan masalah permukiman atau perdagangan. Oleh Karena itu, sangat diperlukan adanya kepastian hukum, yang diperoleh dengan adanya Pendaftaran Tanah.

Dengan adanya pendaftaran tanah akan dapat mengerti dengan segera tentang hakatas $\operatorname{tanah}^{8}$ :

a. Status dan kedudukan;

b. Luas dan batas;

c. Subyek;

d. Beban;

yang melekat pada hak atas tanah tersebut, karena telah terjamin kepastian hukumnya.

Pengaturan tentang Pendaftaran Tanah diatur di Bagian II Pasal 19 Undang-Undang Pokok Agraria, yaitu untuk menjamin kepastian hukum oleh pemerintah diadakan pendaftaran tanah di seluruh wilayah Republik Indonesia menurut ketentuanketentuan yang diatur dengan Peraturan Pemerintah.

Dalam Pasal 19 ayat (2) UUPA pendaftaran tersebut dalam ayat (1) meliputi:

a. Pengukuran, perpetaan dan pembukuan tanah;

b. Pendaftaran hak-hak atas tanah dan peralihan hak-hak tersebut;

c. Pemberian surat-surat tanda bukti hak, yang berlaku sebagai alat pembuktian yang kuat.

Pasal 19 UUPA bermaksud agar masyarakat di seluruh Wilayah Indonesia dapat melakukan pendaftaran tanah yang bersifat rechts kadaster, artinya jaminan kepastian hukum diperoleh oleh para pendaftar tanah. Ketentuan pasal 19 UndangUndang Pokok Agraria untuk menjamin kepastian hak dankepastian hukum pendaftaran tanah,proses dilapangan tidak dapat dipisahkan dengan kegiatan pengukuran dan pembukuan tanah, pendaftaran hak-hak dan peralihan hak-hak tersebut serta pemberian surat tanda bukti hak, yang merupakan paket kegiatan yang ditentukan oleh UndangUndang.

Setelah Undang-Undang Pokok Agraria sebagai pelaksanaan Pasal 19,lahir PP No. 10 Tahun 1961

\footnotetext{
8 Whisnoe Junaidy, Materi Kuliah Akta Tanah, Yogyakarta, 2003, Hal. 3
} 
tentang Pendaftaran Tanah, Karena Pasal 19 UUPA ini menghendaki ada Peraturan Pelaksanaan yang mengatur tata cara Pendaftaran Tanah. Kemudian diperbarui dengan dikeluarkannya PP Nomor 24 Tahun 1997 tentang Pendaftaran Tanah.

Sistem pendaftaran tanah setelah UUPA mewajibkan departemen Agraria waktu itu untuk menerbitkan buku tanah. Buku tanah adalah tempat di lakukannya pendaftaran hak atas tanah, peralihan hak dan pembebanan hak maupun lahirnya hak ataupun hapusnya hak atas tanah, yang sebelumnya kegiatan pendaftaran tanah tidak pernah melakukan hal tersebut.Sebagai tuntutan sistem pendaftaran hak sesuai UUPA, dimana buku tanah tempat pendaftaran hak yang dialihkan atau dibebankan berdasarkan akta PPAT, maka akta yang dibuat para PPAT haruslah dipastikan kebenaran formalnya sehingga Departemen Agraria/BPN perlu untuk menerbitkan blangko akta yang dapat di kontrol kebenarannya dengan kode dan nomor tertentu untuk menjamin kebenaran formal akta tersebut.

Badan Pertanahan Nasional merupakan pejabat satu-satunya yang secara khusus melakukanpendaftaran tanah dan menerbitkan surat bukti haknya (recording of title and continuos recording) ${ }^{9}$

Unsur-unsur pendaftaran tanah adalah :

a. Suatu rangkaian kegiatan, menunjuk kepada adanya berbagai kegiatan dalam penyelenggaraan pendaftaran tanah, yang berkaitan satu dengan. yang lain, berurutan menjadi satu kesatuan rangkaian yang bermuara pada tersedianya data yang diperlukan dalam rangka memberikan jaminan kepastian hukum dalam bidang pertanahan bagi rakyat.

b. Kata-kata terus menerus, menunjuk kepada pelaksanaan kegiatan, yang sekali dimulai tidak akan ada akhirnya. Data yang sudah terkumpul dan sudah tersedia harus selalu dipelihara, dalam arti disesuaikan dengan perubahan-perubahan yang terjadi kemudian, hingga tetap sesuai dengan keadaan yang terakhir.

c. Kata teratur menunjukkan bahwa semua kegiatan harus berlandaskan peraturan perundangundangan yang sesuai, karena hasilnya merupakan data bukti menurut hukum, biarpun daya kekuatan pembuktiannya tidak selalu sama dalam hukum negara-negara yang menyeleng-

\footnotetext{
${ }^{9}$ J. Kartini Soedjendro, Perjanjian Peralihan hak atas tanah yang berpotensi konflik, (Yogyakarta, Kanisius, 2001), hal 69
}

garakan pendaftaran tanah.

Data yang dihimpun pada dasarnya meliputi 2 bidang, yaitu :

1). Data fisik mengenai tanahnya : lokasinya, batas-batasnya, luasannya bangunan dan tanaman yang ada di atasnya;

2). Data yuridis mengenai haknya : haknya apa, siapa pemeganghaknya dan ada atau tidak ada hak pihak lain.

d. Yang dimaksudkan dengan wilayah adalah wilayah kesatuan administrasi pendaftaran, yang bisa meliputi seluruh negara, bisa juga desa atau kelurahan seperti yang ditetapkan dalam Peraturan Pemerintah Nomor 24 tahun 1997 tentang Pendaftaran Tanah

e. Kata-kata tanah-tanah tertentu menunjuk kepada objek pendaftaran tanah.

f. Urutan kegiatan pendaftaran tanah adalah, pengumpulan datanya, pengolahan atau processingnya, penyimpananya dan kemudian penyajiannya $^{10}$

Tujuan dari pendaftaran tanah tercantum dalam Pasal 3 PP Nomor 24 tahun 1997 tentang Pendaftaran Tanah.

Pendaftaran tanah bertujuan untuk menjamin kepastian hukum dan kepastian hak-hak atas tanah. Dengan adanya pendaftaran tanah tersebut terdapatlah jaminan tertib hukum dan kepastian hak atas tanah. Sesuai dengan tujuan pendaftaran tanah, maka Undang-Undang pokok Agraria menghendaki agar untuk pendaftaran itu diwajibkan kepada parapemegang hak ${ }^{11}$

Di Indonesia ini terdapat dua sistem pendaftaran tanah, yaitu :

a. Sistem Publikasi Positif dan

b. Sistem Publikasi Negatif.

Sistem publikasi positif dengan menggunakan sistem pendaftaran hak, maka harus ada register atau buku tanah sebagai suatu penyimpanan dan penyajian data yuridis sertadapat digunakan sebagai tanda bukti hak berupa sertifikat asli. Dalam sistem ini, data yang tercatat dalam buku register dapat dipergunakan sebagai pembuktian yang mutlak.

Dalam sistem publikasi negatif, yang mendasar adalah perbuatan hukum berpindahnya hak dari

\footnotetext{
${ }^{10}$ Boedhi harsono, Hukum Agraria Indonesia, sejarah pembentukan Undang-Undang Pokok Agraria, isi dan pelaksanaannya, Jakarta, Djambatan, 2007, hal. 72-73

${ }^{11}$ Ali achmad chomzah, Hukum Agraria (pertanahan Indonesia) jilid 2, Jakarta, Prestasi Pustaka Publisher, 2004, hal. 6
} 
penjual kepada pembeli bukan pendaftaran peralihan haknya. Pendaftaran tidak membuat orang yang mendapat tanah dari yang tidak berhak, menjadi pemegang hak atas tanah yang baru. Dalam sistem ini berlaku asas nemo plus iuris in alium transferre potest quam ipse habet artinya orang tidak dapat menyerahkan atau memindahkan hak melebihi apa yang dia sendiri punyai ${ }^{12}$

BPN melalui Kantor Pertanahan di setiap Kabupaten di seluruh wilayah Indonesia adalah pelaksana pendaftaran tanah sebagaimana tercantum dalam Pasal 6 PP Nomor 24 tahun 1997 tentang Pendaftaran Tanah. Dalam pelaksanaan pendaftaran tanahnya Kepala Kantor Pertanahan di setiap kabupaten dibantu oleh PPAT dan Pejabat lain yang bertugas melaksanakan kegiatan tertentu seperti yang ditentukan oleh Undang-Undang.

\section{Pengertian Hak-hak Atas Tanah}

Sebelum berlakunya Undang-Undang Pokok Agraria (UUPA), hak atas tanah terdiri dari Hak Barat dan Hak Adat. Hak Barat merupakan keseluruhan kaidah yang bersumber pada hukum perdata barat khususnya Kitab Undang-Undang Hukum Perdata (Burgerlijk Wetboek). ${ }^{13}$ Yang termasuk dalam tanahtanah hak barat yaitu Hak Eigendom, Hak Opstal, Hak Erpacht, dan lain-lain. Tanah barat yang tunduk pada hukum barat artinya hak-hak dan kewajibankewajiban pemegang haknya, persyaratan bagi pemegang hak, hal-hal mengenai tanah yang dihaki, serta perolehannya, pembebasannya dengan hakhak lain, pemindahan haknya, hapusnya dan pendaftarannya diatur menurut ketentuan hukum tanah barat.

Sedangkan untuk Hukum Pertanahan Adat, yaitu keseluruhan kaidah hukum Pertanahan yang bersumber pada hukum adat. ${ }^{14}$ Yang termasuk tanah Adat adalah hak ulayat, tanah hak yasan, tanah hak gogolan/pekulen/sanggan dan lain-lain. Tanah-tanah adat tersebut hampir semuanya belum terdaftar dalam arti dihimpun dan disediakan data fisik dan data yuridis tanah dan hak yang bersangkutan dalam rangka menjamin kepastian hukum dan kepastian hak di bidang pertanahan.

Dalam hukum agraria, tanah adalah bagian dari bumi yang disebut permukaan bumi. Tanah

\footnotetext{
${ }^{12}$ Boedhi harsono, op. cit, hal. 76

${ }^{13}$ Haryati, et.al, Hukum Pertanahan, (Fakultas Hukum : Universitas 17 Agustus 1945, Semarang), 2009, hal. 7 ${ }^{14}$ Ibid
}

yang dimaksudkan di sini adalah tanah dalam pengertian yuridis yang disebut hak.

Selain itu dalam Pasal 33 ayat (1) UUD 1945, dikatakan bahwa "bumi air dan ruang angkasa, termasuk kekayaan alam yang terkandung didalamnya itu, pada tingkatan tertinggi dikuasai oleh Negara ". Negara sebagai organisasi kekuasaan seluruh rakyat. Hak menguasai dari Negara termaksud dalam UUPA (pasal 1 ayat 2).

Hak-hak atas tanah yang dapat dimiliki oleh warga negara yang ada Indonesia antara lain adalah Hak Milik, Hak Guna Usaha, Hak Guna Bangunan dan Hak Pakai.

Hak Milik menurut Pasal 20 ayat (1) UUPA adalah hak turun temurun, terkuat dan terpenuh yang dapat dipunyai orang atas tanah dengan mengingat Pasal 6 UUPA. Hak Milik dapat beralih dan dialihkan kepada pihak lain. UUPA

Hak Guna Usaha adalah hak untuk mengusahakan tanah yang dikuasai langsung oleh Negara dalam jangka waktu sebagaimana tersebut dalam pasal 29, guna perusahaan pertanian, perikanan atau peternakan. Hak Guna Usaha dapat dijadikan jaminan utang dengan dibebani Hak Tanggungan, dapat beralih atau dialihkan dengan cara : Jual beli, Tukar menukar, Penyertaan dalam modal, Hibah, Pewarisan.

Hak Guna Bangunan adalah hak untuk mendirikan dan mempunyai bangunan-bangunan atas tanah yang bukan miliknya sendiri, dengan jangka waktu paling lama 30 tahun. Hak Guna Bangunan dapat dijadikan jaminan utang dengan dibebani Hak Tanggungan (HT hapus dengan hapusnya HGB). Dapat beralih dan dialihkan kepada pihak lain karena : Jual Beli, Tukar Menukar, Penyertaan dalam modal, Hibah, Pewarisan.

Hak Pakai adalah hak untuk menggunakan dan/atau memungut hasil dari tanah yang dikuasai langsung oleh Negara

Tanah komunal atau tanah yang disebut sebagai milik Bersama adalah tanah milik masyarakat adat yang awal kepemilikannya dimulai dengan menduduki wilayah tanah tersebut.Di daerah pelosok diluar jawa, tanah sebagaimana tersebut diakui oleh Hukum Adat yang tidak tertulis yang mendasarkan hubungan darah maupun wilayah. Namun dengan semakin berubahnya sosial ekonomi manusia, tanah komunal mulai dikuasai oleh masyarakat dengan cara penggarapan secara bergilir sehingga lama kelamaan dikenal sistem pemilikan individual. Situasi ini terus berlangsung di dalam wilayah kerajaan dan 
kesultanan sejak abad ke lima dan berkembang seiring kedatangan kolonial Belanda pada abad ke tujuh belas yang membawa konsep hukum pertanahan.

\section{Pengertian Jual Beli}

Menurut Pasal 1457 KUHPerdata yang dimaksud dengan Jual Beli adalah suatu persetujuan dengan mana pihak yang satu mengikatkan dirinya untuk menyerahkan suatu kebendaan dan pihak yang lain untuk membayar harga yang telah diperjanjikan. Pasal 1458 KUHPerdata menyebutkan : "Jual Beli dianggap telah terjadi antara kedua pihak seketika setelah orang-orang ini mencapai kata sepakat tentang kebendaan tersebut dan harganya, meskipun benda tersebut belum diserahkan dan harganya belum dibayar".

Jual beli hak atas tanah dalam hukum adat bersifat perbuatan hukum dua pihak yang artinya penyerahan hak atas tanah yang disertai dengan pembayaran kontan dari pihak pembeli pada saat itu juga.

Pengertian Jual Beli hak atas tanah dalam hukum adat adalah perbuatan hukum yang berupa penyerahan tanah yang bersangkutan oleh penjua kepada pembeli pada sat mana pihak pembeli menyerahkan pembayarannya kepada penjual. ${ }^{15}$ Pada umumnya sebagai bukti bahwa telah dilakukan jual beli, para pihak dibuatkan suatu akta jual beli yang kemudian ditanda tangani (cap jempol) oleh penjual dan pembeli serta dibubuhi pula tanda tangan dari kepala desa/kepala adat dan saksi-saksi.

Pada masyarakat hukum adat, penyelenggaraan pendaftaran tanah bukan merupakan suatu keharusan. Hal ini disebabkan bahwa karena kehidupan masyarakat adat terbatas luas lingkungan dan jumlah penduduknya. Sehingga jika melakukan jual beli maka masyarakat akan mengetahuinya atau setidaknya kepala desa/kepala adatnya dan orang lain akan memperoleh keterangan dengan mudah dari kepala desa/kepala adatnya.

Jual beli merupakan salah satu perjanjian pada umumnya yang diatur dalam Buku III KUHPerdata. Pasal 1338 ayat (1) KUHPerdata berbunyi "semua persetujuan yang dibuat secara sah berlaku sebagai undang-undang bagi mereka yang membuatnya" sehingga jual beli menurut Hukum Barat (BW) menganut sistim terbuka dan asas kebebasan berkontrak. Kita bebas untuk membuat suatu

\footnotetext{
${ }^{15}$ Haryati. et. Al, op.cit, hal. 160
}

perjanjian asal tidak melanggar kepatutan, ketertiban umum dan kesusilaan.

Penyerahan hak milik atas tanah atau biasa disebut levering merupakan suatu perbuatan yuridis guna memindahkan hak milik. Untuk barang tidak bergerak seperti tanah, penyerahan (levering) dilakukan dengan cara "balik nama" dihadapan Pegawai Kadaster atau Pejabat Balik Nama (Overschrijving Ambternaar). Namun pasal-pasal dalam KUHPerdata tersebut belum sampai dikeluarkan atau belum pernah berlaku telah dicabut terlebih dahulu digantikan dengan Undang-Undang Pokok Agraria.

Pengertian jual beli tanah menurut UndangUndang Pokok Agrariamendasarkan pada arti jual. Pengertian jual beli yang bersifat umum yaitu suatu perbuatan dimana seseorang melepaskan uang untuk mendapatkan barang yang dikehendaki secara sukarela. Yang terpenting ada pihak yang menjual sedangkan dari pihak lain dinamakan membeli, jadi dalam hal ini terdapat dua pihak yaitu penjual dan pembeli yang bertimbal balik. ${ }^{16}$

Berdasarkan ketentuan diatas, barang yang menjadi obyek perjanjian jual beli harus cukup tertentu, setidak-tidaknya dapat ditentukan wujud dan jumlahnya pada saat akan diserahkan hak miliknya kepada si pembeli ${ }^{17}$. Unsur-unsur pokok (essentialia) dalam perjanjian jual beli yaitu barang dan harga. Unsur-unsur sebagaimana Pasal 1333 dan Pasal 1334 KUHPerdata bias berupa baran tidak bergerak (tanah, bangunan dan rumah) dan barang bergerak. Demikian juga bisa berupa barang yang sudah ada maupun barang yang akan ada dikemudian hari. Untuk unsur harga sebagaimana Pasal 1465 KUHPerdata menyebutkan bahwa "harga beli harus ditetapkan oleh kedua belah pihak". Tidak hanya itu, harga harus sesuai dengan nilai barang.

Dalam perjanjian jual beli yang terdapat penjual dan pembeli memiliki hak dan kewajiban yang bertimbal balik, bagi si penjual berkewajiban untuk menyerahkan hak milik atas barang yang diperjualbelikan serta menjamin kenikmatan tenteram alas barang tersebut dan menanggung terhadap cacad-cacad yang tersembunyi dan terhadapnya berhak untuk menerima pembayaran harga barang, sedangkan kewajiban si pembeli, yang utama adalah membayar harga yang berupa sejumlah uang pada saat pembelian pada waktu dan

\footnotetext{
${ }^{16}$ Subekti, aneka perjanjian, cc. 10, Bandung, Citra Aditya Bakti, 1995, hal. 1

${ }^{17}$ Ibid, hal. 2
} 
ditempat sebagaimana yang ditetapkan menurut perjanjian, sedangkan haknya adalah menerima barang yang diperjualbelikan dari penjual tersebut. ${ }^{18}$

\section{Pengertian Peralihan Hak}

Menurut Lili Rasjidi, "bahwa suatu hak itu mengharuskan kepada, orang yang terkena hak itu untuk melakukan suatu perbuatan atau tidak melakukan sesuatu". ${ }^{19}$

Peralihan hak atas tanah menurut UUPA adalah setiap perjanjian yang bermaksud mengalihkan hak atas tanah dan pelaksanaannya harus dilakukan dan dibuktikan dengan suatu akta Pejabat Pembuat Akta Tanah (PPAT).

Dalam Pasal 19 PP No. 10 Tahun 1961 menyatakan :

Setiap perjanjian yang bermaksud memindahkan hak atas tanah, memberikan sesuatu hak baru atas tanah, menggadaikan tanah atau meminjam uang dengan hak atas tanah sebagai tanggungan, harus dibuktikan dengan suatu akta yang dibuat oleh dan dihadapan pejabat yang ditunjuk oleh Menteri Agraria.

Dalam hal ini yang termasuk "peralihan hak atas tanah tidak hanya meliputi jual beli tetapi dapat juga terjadi karena hibah, tukarmenukar, pemberian dengan wasiat dan perbuatan-perbuatan lain yang bermaksud memindahkan hak pemilikan tanah". ${ }^{20}$ Namun yang sering terjadi di masyarakat adalah peralihan hak melalui jual beli. Peralihan hak atas tanah adalah perbuatan hukum pemindahan hak atas tanah yang dilakukan dengan sengaja supaya hak tersebut terlepas dari pemegangnya semula dan menjadi hak pihak lain. ${ }^{21}$

Pasal 37 ayat 1 PP Nomor 24 Tahun 1997, ditegaskan bahwa:

Peralihan hak atas tanah dan hak milik atas satuan rumah susun melalui jual beli, tukar menukar, hibah, pemasukan data perusahaan dan perbuatan hukum pemindahan hak lainnya, kecuali pemindahan hak melalui lelang hanya dapat didaftarkan jika dibuktikan dengan akta

\footnotetext{
${ }^{18}$ Subekti, Pokok-pokok Dari Hukum Perdata, cct 11, Jakarta, Intermasa, 1975, hal 135

${ }^{19}$ Lili Rasjidi, Filsafat Hukum, Bandung, Remaja Karya, 1998, hal 73

${ }^{20}$ Ali Ahmad Chomzah, Hukum Pertanahan, Pemberian Hak Atas Tanah Negara, Jakarta Prestasi Pustaka, 2002, hal 15

${ }^{21}$ K.Wantjik Saleh, Hak anda atas tanah, Jakarta, Ghalia Indonesia, 1997, hal. 15-18
}

yang dibuat oleh PPAT yang berwenang menurut ketentuan peraturan perundang-undangan yang berlaku.

Guna menjamin kepastian hukum pemilikan hak atas tanah, maka peralihan hak harus dilaksanakan dihadapan PPAT.Akta Jual Beli yang dibuat dihadapan PPAT tersebut bertujuan untuk memberikan kepastian hukum kepada pemegang hak atas suatu bidang tanah (pembeli tanah). ${ }^{22}$

\section{Peranan PPAT Dalam Pendaftaran Tanah}

Dalam PP No. 37 Tahun 1998 tentang Peraturan Jabatan Pejabat Pembuat Akta Tanah menyebutkan bahwa salah satu tugas pokok PPAT adalah membantu Pemerintah dengan melakukan sebagian kegiatan pendaftaran tanah, sebagaimana dimaksudkan dalam Pasal 2 ayat (1) PP No. 37 Tahun 1998 yang berbunyi "PPAT bertugas pokok melaksanakan sebagian kegiatan pendaftaran tanah dengan membuat akta sebagai bukti telah dilakukannya perbuatan hukum tertentu mengenai hak atas tanah atau Hak Milik atas satuan Rumah Susun, yang akan dijadikan dasar bagi pendaftaran perubahan data pendaftaran tanah yang diakibatkan oleh dan hak milik atas satuan rumah susun yang terletak di dalam daerah perbuatan hukum itu.

Akta-akta yang dapat dipergunakan sebagai dasar hukum pemindahan hak atas tanah harus memenuhi syarat-syarat yang ditentuan oleh peraturan hukum yang berlaku yaitu dalam hal bukti kepemilikannya harus jelas yaitu siapa yang berhak sebenarnya dan dalam keadaan sengketa atau tidak.

Sesuai dengan ketentuan Pasal 19 UUPA yang menghendaki diselenggarakannya pendaftaran hak atas tanah di Indonesia. Pengaturan mengenai pendaftaran tanah diselenggarakan dengan berpedoman pada Peraturan Pemerintah Nomor 24 Tahun 1997. Dalam pelaksanaan administrasi pertanahan, data pendaftaran tanah yang tercatat di Kantor Pertanahan harus sesuai dengan keadaan bidang tanah yang bersangkutan baik yang menyangkut data fisik maupun data yuridis tanah. Dalam pencatatan data yuridis ini khususnya pencatatan perubahan data yang sudah tercatat sebelumnya maka peranan PPAT sangatlah penting.

PPATsebagai pejabat umum yang diberi

\footnotetext{
${ }^{22}$ Saleh Adiwinata, Pengertian Hukum Adat menurut Undang-Undang Pokok Agraria, Bandung Alumni, 1980, hal $21-30$
} 
wewenang untuk membuat akta- akta dalam peralihan hak atas tanah, akta pembebanan serta surat kuasa pembebanan hak tanggungan, juga bertugas membantu Kepala Kantor Pertanahan Nasional dalam melaksanakan pendaftaran tanah dengan membuat akta-akta tertentu sebagai bukti telah dilakukannya perbuatan hukum tertentu mengenai hak atas tanah dan atau bangunan yang akan dijadikan dasar bagi bukti pendaftaran tanah.PPAT sudah dikenal sejak berlakunya Peraturan Pemerintah Nomor 10 Tahun 1961 tentang Pendaftaran Tanah, yang merupakan peraturan tanah sebagai pelaksana UUPA.

J. Kartini Soedjendro menyatakan bahwa:Secara fungsional, jabatan PPAT dan Notaris adalah ibarat dua sisi dari satu mata uang. Artinya, walaupun jabatannya berbeda, namun mempunyai fungsi dan kedudukan yang sama selaku pejabat umum pembuat akta yang saling terikat. Dikatakan demikian karena perbedaanjenis akta yang dibuat masing-masing tidak terletak pada bobot keabsahan dan kekuatan hukumnya, tetapi hanya terletak padaperbedaan bidang hukum yang mereka tangani. ${ }^{23}$

Mengingat pentingnya fungsi PPAT perlu kiranya diadakan peraturan tersendiri yang mengatur tentang PPAT sebagaimana yang ditetapkan dalam Pasal 7 ayat 3 Peraturan Pemerintah Nomor 24 Tahun 1997, demikian juga setelah dikeluarkannya Peraturan Pemerintah Nomor 37 Tahun 1998 tentang Peraturan Pejabat Pembuat Akta Tanah. Berdasarkan Pasal 1 angka 1 Peraturan Pemerintah Nomor 37 Tahun 1998 dikatakan PPAT adalah "pejabat" umum yang diberi kewenangan untuk membuat akta-akta otentik mengenai perbuatan hukum tertentu mengenai hak atas tanah atau hak atas satuan rumah susun".

Berdasarkan pasal tersebut diatas, maka pada dasarya kewenangan PPAT berkaitan erat dengan perbuatan hukum tertentu mengenai hak atas tanah atau hak milik atas satuan rumah susun. Untuk membuktikan adanya perbuatan hukum pengalihan hak atas tanah danatau bangunan haruslah dibuat akta otentik. Tanpa adanya akta otentik maka secara hukum perbuatan hukum untuk mengalihkan suatu hak atas tanah dan bangunan belum sah.

PPAT sebagai pejabat umum, maka akta yang dibuatnya diberi kedudukan sebagai akta otentik,

${ }^{23}$ J. Kartini Soedjindro, Perjanjian Hak Atas Tanah Yang Berpotensi Konflik, Yogyakarta, Kanisius, 2001, hal. 26 yaitu akta yang dibuat untuk membuktikan adanya perbuatan hukum tertentu yang fnengakibatkan terjadinya peralihan hak atas tanah dan bangunan.

Berkaitan dengan kepastian pemilikan hak atas tanah dan bangunan, setiap perolehan hak yang terjadi dari suatu perbuatan hukum harus dibuat dengan akta otentik. Hal ini penting untuk memberi kepastian hukum bagi pihak yang memperoleh hak tersebut sehingga ia dapat mempertahankan haknya tersebut dari gugatan pihak manapun.

Tanpa adanya akta otentik maka secara hukum perolehan hak tersebut belum diakui dan sebenarnya hak atas tanah dan bangunan masih ada pada pihak yang mengalihkan hak tersebut. Untuk melindungi pihak yang memperoleh hak, maka akta otentik yang dibuat pada saat perolehan hak dilakukan merupakan alat pembuktian yang kuat yang menyatakan adanya perbuatan hukum peralihan hak atas tanah dan bangunan yang dimaksud kepada pihak yang dinyatakan memperoleh hak tersebut.

Adanya akta PPAT yang bermaksud membuat akta perjanjian pengalihan hak atas tanah dan hak milik atas satuan rumah susun melalui jual beli, penukaran, hibah, pemasukan dalam perusahaan dan perbuatan hukum pemindahan hak lainnya, kecuali pemindahan hak karena lelang yang hanya dapat didaftarkan jika dibuktikan dengan akta yang dibuat oleh PPAT yang berwenang dan jika akta peralihan hak atas tanah dan hak milik atas satuan rumah susun tersebut sudah didaftarkan oleh kepala kantor pertanahan dalam daftar buku tanah, maka kepala kantor pertanahan memberikan sertipikat hak atas tanah atau hak milik atas satuan rumah susun yang bersangkutan kepada pembeli.

\section{Prosedur Pembuatan Akta PPAT}

Berkaitan dengan jual beli tanah, terdapat 2 (dua) syarat yang harus dipenuhi berkaitan dengan tata cara pembuatan akta PPAT, yukni syarat formil dan syarat materil. Adapun syarat formil dari tata cara pembuatan akta HAT tersebar dalam berbagai peraturan yang terkait kePPAT-an. Mengenai bentuk dan tata cara pembuatan akta PPAT didasari oleh Pasal 24 PP No. 37 Tahun 1998 tentang Peraturan Jabatan PPAT yang menentukan "Ketentuanketentuan lebih lanjut mengenai tata cara pembuatan akta PPAT diatur dalam peraturan perundang-undangan mengenai pendaftaran tanah." Ketentuan dalam PP No. 24 Tahun 1997 tentang Pendaftaran Tanah yang mengatur mengenai hal ini 
ditegaskan pada Pasal 38 ayat 86 (2) yang menentukan "Bentuk, isi dan cara pembuatan aktaakta PPAT diatur oleh Menteri". Peraturan yang dimaksud adalah PMNA/Ka BPN No. 3 Tahun 1997 tentang Ketentuan Pelaksanaan PP No. 24 Tahun 1997 tentang Pendaftaran Tanah, yang diatur pada Pasal 95-102. Ketentuan formil lainnya dapat juga ditemui pada Pasal 21-24 PP No. 37 Tahun 1998 tentang PJPPAT, Pasal 51-55 Perka BPN No. 1 Tahun 2006 tentang Ketentuan Pelaksanaan PP No. 37 Tahun 1998 tentang Peraturan Jabatan PPAT, dan peraturan yang berkaitan dengan perpajakan. ${ }^{24}$

\section{PENUTUP}

\section{Kesimpulan}

1) Perbuatan hukum yang bagaimana yang dapat dikatakan sebagai yang tidak sesuai dengan prosedur pembuatan akta oleh PPAT

a. Penandatanganan akta jual beli telah dilakukan akan tetapi para pihak belum melakukan pembayaran pajak, yakni Pajak Penghasilan (PPh) atas penghasilan dari pengalihan hak atas tanah dan/atau bangunan bagi Penjual, dan Pajak Bea Perolehan Hak Atas Tanah dan Bangunan (BPHTB) bagi Pembeli.

b. Penandatanganan akta jual beli oleh para pihak dilakukan tidak dihadapan PPAT yang menandatangani akta jual beli (titipan akta). Penandatanganan akta jual beli oleh penjual dan pembeli tidak dilakukan dalam waktu yang bersamaan di hadapan PPAT.

c. Jual beli telah ditandatangani tapi sertipikat belum diperiksa kesesuaiannya dengan buku tanah di kantor pertanahan.

d. Pembuatan akta jual beli dilakukan di luar daerah kerja PPAT tanpa kuasa dan tanpa dihadiri oleh saksi-saksi.

e. PPAT tidakmembacakan isi dari akta jual beli dihadapan para pihak secara terperinci, hanya menjelaskan mengenai maksud dari pembuatan akta.

f. Selambat-lambatnya 7 (tujuh) hari kerja sejak ditandatanganinya akta yang bersangkutan, PPAT wajib menyampaikan akta yang di buatnya berikut dokumen-dokumen yang

\footnotetext{
${ }^{24}$ Ketentuan formil mengenai tata cara pembuatan akta PPAT yang diatur pada PMNA/Ka BPN No. 3 Tahun 1997 tentang Ketentuan Pelaksanaan PP No. 24 Tahun 1997 tentang Pendaftaran Tanah.
}

bersangkutan kepada Kantor Pertanahan untuk di daftar.

2) Akibat hukum dari akta jual beli tanah yang dibuat tidak sesuai dengan prosedur pembuatan akta PPAT tersebut adalah sebagai berikut:

a. Terdegradasinya akta yang semula otentik menjadi akta dibawah tangan.

b. Bagi PPAT yang bersangkutan dapat dikenakan sanksi berupa harus membayar biaya, denda dan bunga, bahkan bias bermuara ke ranah pidana jika PPAT yang bersangkutan terbukti melakukan tindak pidana sebagai missal tindak pidana pemalsuan akta.

\section{Saran}

Dari uraian sebagaimana tersebut diatas, maka penulis dapat memberikan saran-saran berupa :

1. Untuk PPAT.

Bagi PPAT dalam menjalankan profesinya sebagai pelayan masyarakat agar tetap mengutamakan prosedur dalam pembuatan akta agar terhindar dari permasalahan hukum baik bagi dirinya sendiri maupun bagi para pihak. Guna mengantisipasi hal tersebut seharusnya PPAT terlebih dahulu memberikan pengertian kepada para klien bagaimana prosedur pembuatan akta yang sesuai dengan prosedur yang ditetapkan oleh Undang-Undang yang berlaku.

2. Untuk para pihak.

Para pihak harus memahami bahwa prosedur yang sesuai dengan ketentuan peraturan perundang-undangan itu sebenarnya guna kepentingan para pihak sendiri. Karena dengan adanya penyimpangan akan mengancam hak kepemilikan yang mereka miliki. Maka dari itu para pihak harus menyadari betapa pentingnya prosedur pembuatan akta yang benar meskipun dapat dibilang tidak gampang danx membutuhkan kesabaran.

\section{DAFTAR PUSTAKA}

\section{BUKU}

Ali Achmad Chomsah, Hukum Agraria (Pertanahan Indonesia) Jilid 2, (Jakarta, Prestasi Pustaka Publiser, 2004) 
Boedi Harsono, Hukum Agraria Indonesia, Sejarah pembentukan Undang-Undang Pokok Agraria, Isi dan pelaksanaannya, (Jakarta, Djambatan, 2007).

Burhan Ashofa, Metode Penelitian Hukum, Jakarta : Rineka Cipta. 1996

Jimly Asshiddiqi, Independen dan Akuntabilitas Pejabat Pembuat Akta Tanah, Majalah Renvoi Edisi 3 Juni 2003

Setiono, Pemahaman terhadap Metode Penelitian Hukum (Diktad), Surakarta : Program Studi Ilmu Hukum Pascasarjana UNS 2002, hlm. 5

Soerjono Soekanto, Pengantar Penelitian Hukum, Jakarta, UI Press, 1986
Sutrisno Hadi, Metodelogi Penelitian Hukum, Surakarta: UNS Press, Surakarta, 1989

Winarno Surakhmad, Pengantar Penelitian IImiah. Yogyakarta : Transito, Yogyakarta, 1990

\section{PERATURAN PERUNDANG-UNDANGAN}

\section{UUD 1945}

UU No. 5 Tahun 1960 tentang Undang-Undang Pokok Agraria

Peraturan Pemerintah No. 24 Tahun 1997

Peraturan Menteri Negara Agraria/Kepala Badan Pertanahan Nasional No. 3 Tahun 1997 